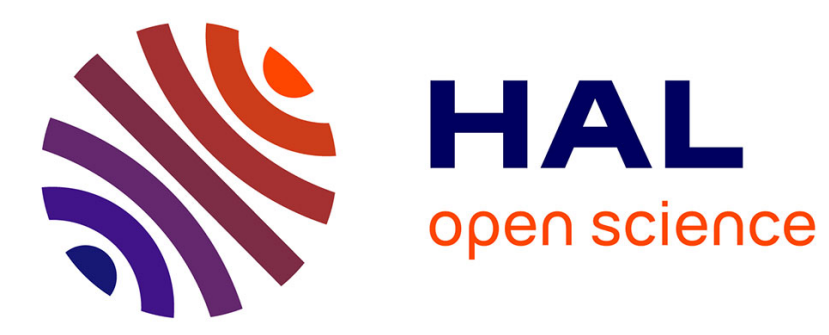

\title{
Going above and beyond the pancreatic neuroendocrine tumor classification
}

Sébastien Gaujoux, Fabrice Menegaux

\section{To cite this version:}

Sébastien Gaujoux, Fabrice Menegaux. Going above and beyond the pancreatic neuroendocrine tumor classification. JCO Oncology Practice, 2020, 16 (11), pp.731-732. 10.1200/OP.20.00809 . hal03262505

\section{HAL Id: hal-03262505 \\ https://hal.sorbonne-universite.fr/hal-03262505}

Submitted on 16 Jun 2021

HAL is a multi-disciplinary open access archive for the deposit and dissemination of scientific research documents, whether they are published or not. The documents may come from teaching and research institutions in France or abroad, or from public or private research centers.
L'archive ouverte pluridisciplinaire HAL, est destinée au dépôt et à la diffusion de documents scientifiques de niveau recherche, publiés ou non, émanant des établissements d'enseignement et de recherche français ou étrangers, des laboratoires publics ou privés. 
Going above and beyond the pancreatic neuroendocrine tumor classification

Sébastien Gaujoux ${ }^{1,2,3}$; Fabrice Menegaux ${ }^{2,3}$

\section{AFFILIATIONS}

1. Department of Hepato-Biliary and Pancreatic Surgery and Liver Transplantation, AP-HP Pitié-Salpêtrière Hospital, Paris

2. Department of General, Visceral, and Endocrine Surgery, Pitié-Salpêtrière Hospital, AP-HP, Paris.

3. Sorbonne University, Paris, France.

\section{CORRESPONDING AUTHOR :}

Pr Sébastien Gaujoux, MD, PhD

Department of Hepato-Biliary and Pancreatic Surgery and Liver Transplantation, AP-HP Pitié-Salpêtrière Hospital, Paris

47-83 Avenue de 1'Hôpital

75013 Paris, France

Professional number: +33184827972

E-mail: sebastien.gaujoux @aphp.fr 
Over the last decades, significant progresses have been made in the diagnosis, understanding of pathophysiology and natural history and management of pancreatic neuroendocrine tumors (PanNETs). Nevertheless, the term of "pancreatic neuroendocrine tumours" encompasses a very large and heterogeneous group of tumours, that can be functional i.e. associated with clinical symptoms in relation with secreted peptides or non-functional, sporadic or from a genetic origin, indolent in the long-term or highly aggressive and shortly life- threatening. Facing such heterogeneous neoplasm/carcinoma, patients' management is highly challenging and as stated by Li and collaborators ${ }^{1}$ in their comprehensive review, given the heterogeneity of these tumors, an individualized approach should be the goal.

In this issue of JCO Oncology Practice, $\mathrm{Li}$ and collaborators ${ }^{1}$ nicely summarized current knowledge of the epidemiology, diagnostic evaluation, pathology assessment, and various treatment modality and strategy in the management of PanNETs, with a specific attention to ongoing controversies and trials. As they underline, several clinically relevant questions remain unanswered.

Radical resection is the only curative option for PanNETs but pancreatic surgery is associated with a significant morbidity and mortality. The mortality of pancreatectomies usually range from $1 \%$ to $4 \%$ in high-volume centers but increases above $10 \%$ when nationwide data are considered ${ }^{2,3}$. This should always be kept in mind when patients are selected for surgery, and the risk- benefit balance of the surgery has to be carefully weighted. Consequently, such resection should only be performed in expert and dedicated centers ${ }^{4-6}$. Surgery and especially patient selection for surgery has recently benefit a better knowledge of the natural history of $<2 \mathrm{~cm}$, asymptomatic, non-functional PanNETs ${ }^{7}$ and of the progress of diagnostic evaluation, including diffusion-weighted MRI and nuclear imaging with the development ${ }^{68} \mathrm{Ga}$ and a metabolic grading FDG PET/CT ${ }^{8}$. These recent progresses should not mask the lack of evidence, and it is important to note the absence of surgical randomized controlled study, while there is an increasing number of oncological randomized controlled trials published or ongoing. The lack of "evidence-based surgery" call for a larger implication of surgeons in true collaborative network. 
Systemic therapies have made a great leap forward in recent years, with the publication of several randomized controlled studies some of them only dedicated to PanNET ${ }^{9}$. Additionally, as summarized in the present review, numerous trials are ongoing, increasing in a near future the armamentarium of treatment options for our patients. If several of these trials are driven by the industry, others are true academic trials, and interestingly trials addressing therapy sequencing such as SEQTOR trial (Efficacy and Safety of Everolimus and (STZ-5FU) Given One Upfront the Other Upon Progression in Advanced PanNET) are also in progress. This is key to study patients having a long-life expectancy, for whom quality of life is key and can be altered by the sequence of treatment.

Up to now, available recommendations are mainly based on 2017 WHO histopronostic classification, regularly updated. There is no doubt, as in many other neoplasms, that genetic testing with next-generation sequencing, will in a near future help to tailor patient's treatment and avoid a one-size- fits-all strategy. This will be at some point included in clinical recommendations to better tailor panNET management and enabling the future of personalized medicine. Nevertheless, in order to accomplish such progresses, we need to build strong collaborative multidisciplinary network including basic scientist, genetician, surgeons, radiologists, interventional radiologist, gastroenterologist pancreatologist, pathologist, diabetologist, psychologist, nutritionist and oncologist.

\section{REFERENCES}

1. Li D, Rock A, Kessler J, et al: Understanding the Management and Treatment of WellDifferentiated Pancreatic Neuroendocrine Tumors: A Clinician's Guide to a Complex Illness. JCO Oncology Practice, 2020

2. Farges O, Bendersky N, Truant S, et al: The Theory and Practice of Pancreatic Surgery in France. Ann Surg 266:797-804, 2017

3. de Wilde RF, Besselink MG, van der Tweel I, et al: Impact of nationwide centralization of pancreaticoduodenectomy on hospital mortality. Br J Surg 99:404-10, 2012 
4. Gooiker GA, Lemmens VE, Besselink MG, et al: Impact of centralization of pancreatic cancer surgery on resection rates and survival. Br J Surg 101:1000-5, 2014

5. Gooiker GA, van Gijn W, Wouters MW, et al: Systematic review and meta-analysis of the volume-outcome relationship in pancreatic surgery. Br J Surg 98:485-94, 2011

6. Ahola R, Siiki A, Vasama K, et al: Effect of centralization on long-term survival after resection of pancreatic ductal adenocarcinoma. Br J Surg, 2017

7. Sallinen VJ, Le Large TYS, Tieftrunk E, et al: Prognosis of sporadic resected small $(</=2 \mathrm{~cm})$ nonfunctional pancreatic neuroendocrine tumors - a multi-institutional study. HPB (Oxford) 20:251-259, 2018

8. Mapelli P, Partelli S, Salgarello M, et al: Dual tracer 68Ga-DOTATOC and 18F-FDG PET/computed tomography radiomics in pancreatic neuroendocrine neoplasms: an endearing tool for preoperative risk assessment. Nucl Med Commun 41:896-905, 2020

9. Raymond E, Dahan L, Raoul JL, et al: Sunitinib malate for the treatment of pancreatic neuroendocrine tumors. N Engl J Med 364:501-13, 2011

\section{AUTHOR CONTRIBUTIONS}

Conception and design: All authors

Financial support: None

Administrative support: NA

Provision of study material or patients: NA

Collection and assembly of data: NA

Data analysis and interpretation: NA

Manuscript writing: All authors

Final approval of manuscript: All authors

Accountable for all aspects of the work: All author 
